\title{
Editor's Introduction
}

\author{
Anna Clark
}

B

eginning this issue, Linda Pollock's article, "Honor, Gender, and Rec-

onciliation in Elite Culture, 1570-1700," makes an important inter-

vention into debates about early modern honor. Historians of the early modern English gentry have emphasized the influence of honor culture, which would seem to mandate a violent response to slights to honor, but the early modern gentry has also been depicted as peaceful and self-controlled. While this pacific nature has been attributed to Protestantism, Pollock argues that the English gentry also espoused a concept of honor that emphasized consensus, moderation, and discipline. An honorable gentleman restrained his anger and did everything he could to reconcile disputes in order to preserve his family's honor; an honorable lady was not only chaste but financially responsible and able to keep the peace. ${ }^{1}$

We then move to the era of the Napoleonic Wars, which historians have recently depicted as a time when Britons united against the French foe, isolated as they were beyond the Continental Blockade, which kept British goods from their markets. But Gavin Daly demonstrates in his article, "English Smugglers, the Channel, and the Napoleonic Wars, 1800-1814," that English fishermen silently sailed with precious cargoes of gold guineas and escaped French prisoners of war, returning across the Channel with brandy, gin, lace, silk, and leather from France. Daly uses this phenomenon to make some interesting observations about frontiers, arguing that "the Channel was not so much a fixed political border as a permeable space that allowed commodities and people to pass into and out of England and France" (31).

Continuing the theme of our last issue, "The Politics of Leisure," Amy WoodsonBoulton's “'Industry without Art Is Brutality': Aesthetic Ideology and Social Practice in Victorian Art Museums" contrasts the artistic policies of Liverpool, Manchester, and Birmingham. John Ruskin inspired reformers to try to build museums to "bring beauty to the masses," but as Woodson-Boulton demonstrates, cities might have other goals, such as bolstering their reputations. Art museums could also enhance the status of the newly wealthy entrepreneurial middle classes of these cities. Woodson-Boulton demonstrates that each of these cities established museums in different ways and for different motives.

${ }^{1}$ This article adds to discussions of honor in Erica Longfellow's "Public, Private, and the Household in Early Seventeenth-Century England," Journal of British Studies 45, no. 2 (April 2006): 313-34; and John Smail's "Credit, Risk, and Honor in Eighteenth-Century Commerce," Journal of British Studies 44, no. 3 (July 2005): 439-56. 
The names of nations have always been extremely important in the British Islesor Great Britain—or the United Kingdom. ${ }^{2}$ Mary Daly explores this issue in "The Irish Free State/Éire/Republic of Ireland/Ireland: 'A Country by Any Other Name'?" When Ireland was partitioned in 1921, the name of the newly independent country became a politically sensitive issue. The south became the Irish Free State, but Britain referred to it as Southern Ireland, or the Dominion, because it did not want to imply that the Free State had a claim over the whole island. A new constitution in 1937 changed the name to Éire, but republicans could still use the name Ireland to imply such a claim. This seemingly technical question had huge political ramifications, which played out in technical negotiations ranging from the postal code to the honorifics of ambassadors.

The last two articles demonstrate key changes in the historiography of sexuality. Historians have assumed that after the repeal of the Contagious Diseases Acts, British treatment of sexually transmitted diseases became much more voluntary on the domestic, although not on the imperial, level. In "Compulsion, Voluntarism, and Venereal Disease: Governing Sexual Health in England after the Contagious Diseases Acts," Pamela Cox demonstrates that more subtle forms of coercion continued into the twentieth century. Furthermore, the focus of treatment expanded beyond prostitutes, soldiers, and sailors to include pregnant women, mothers, babies, children, merchant seamen, delinquent girls, and the mentally defective. Cox also makes the conceptually interesting point that these people were not treated by legally mandated official clinics but through the voluntary sector, in clinics, hospitals, and charitable homes. Cox asserts that these were forms of coercion that officially "didn't happen." The unknown, the unacknowledged, the open secret is an important aspect of the history of sexuality that has been neglected with the focus on discourses and experts.

Joseph Bristow's survey article, "Remapping the Sites of Modern Gay History: Legal Reform, Medico-Legal Thought, Homosexual Scandal, Erotic Geography," explores the remarkable outpouring of new work on male homosexuality in the nineteenth and twentieth centuries to assess its relationship to an older historiographical and theoretical framework. Many younger historians challenge what they see as Jeffrey Weeks's and Michel Foucault's insistence that male homosexual identity emerged only through the discourses of experts such as sexologists. Bristow points out that Foucault, and especially Weeks, were much more subtle and nuanced than this interpretation. Nonetheless, in defining themselves in opposition to them, younger historians shed new light on the relationship between the law, sexological discourses, and scandals on homosexual identity, and they also map new geographies of sex.

2 See Alan MacColl, "The Meaning of 'Britain' in Medieval and Early Modern England," Journal of British Studies 45, no. 2 (April 2006): 248-69. 